\title{
Does Okun's Law Exist in Nigeria? Evidence from the ARDL Bounds Testing Approach
}

\author{
Nurudeen $\mathrm{Abu}^{1,2}$
}

\begin{abstract}
This study employs the autoregressive distributed lag (ARDL) bounds testing technique to examine whether Okun's law exists in Nigeria during 1970-2014. In addition, this study considers the role of oil prices in the Nigerian economy. The empirical results indicate that a cointegrating or long term relationship exists between the unemployment rate, economic growth and oil prices. In addition, the results demonstrate that in Nigeria, in the long term, unemployment has a negative and significant effect on economic growth, and oil prices have a significant and positive effect on economic growth. The coefficient of unemployment $(0.18 \%)$ for this study is far less than the result reported by Okun and other studies that focused on developed countries. This suggests that the Okun coefficient is not only unstable but varies for different countries, and does not remain constant for Nigeria. However, policymakers should take steps to reduce unemployment to enhance economic growth in Nigeria.
\end{abstract}

KEY WORDS: $\quad$ Unemployment, Output growth, Okun's law, Nigeria, ARDL

JEL Classification: $\quad$ O04, E02

'Umaru Musa Yar'adua University, Katsina, Nigeria; ${ }^{2}$ Department of Economics, Umaru Musa Yar'adua University, Katsina

\section{Introduction}

The relationship between unemployment and economic growth has been extensively studied since Okun's study in 1962 (cited in Farsio \& Quade, 2003), which determined that when unemployment is reduced by 1 percentage point, GNP increases by approximately $3 \%$. Scholars have evaluated the link between unemployment and economic growth by either regressing output on the unemployment rate or regressing unemploy-

\section{-}

Correspondence concerning this article should be addressed to: Nurudeen Abu, Department of Economics, Umaru Musa Yar'adua University, PMB 2218, Katsina, Nigeria E-mail: abu. nurudeen@yahoo.com ment on output growth. Certain studies have tested Okun's hypothesis and reported mixed results because they used different datasets, various estimation techniques, various time periods, and different countries with disparate features. Some studies have determined that output growth has a negative effect on unemployment (see Ball, Leigh, \& Loungani, 2013; Moosa, 1997; Silvapulle, Moosa, \& Silvapulle, 2004; Sogner, 2001). The results from these studies suggest that increases in output are required to reduce unemployment. Other studies have verified that Okun's law exists because they determined that unemployment has a negative impact on output (see Farsio \& Quade, 2003; Hamada \& Kurosaka, 1984; Izyumov \& Vahaly, 2002; Noor, 


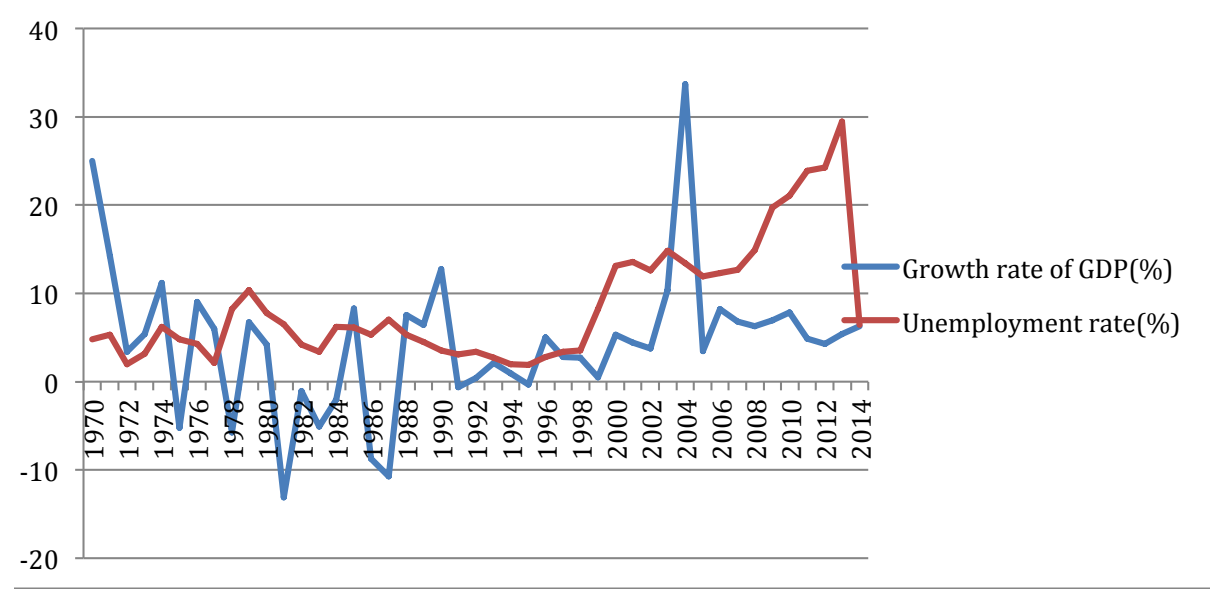

Figure 1. Plots of Nigeria's unemployment rate and GDP growth rate

Nor, \& Ghani, 2007; Zagler, 2003). Furthermore, other studies observed a feedback or reversed relationship between unemployment and output (see Evans, 1989; Kargi, 2014), and yet other studies refuted the existence of Okun's law (Zagler, 2003).

The attainment of high growth rates and full employment are top priorities for developed and developing countries. Unfortunately, Nigeria has reported high unemployment rates and unimpressive growth rates. Figure 1 illustrates the economic growth plots (measured by GDP growth rates) and unemployment rates. Most countries face challenges related to unemployment and growth, which can be more devastating for developing countries such as Nigeria. Unemployment has been a serious issue in Nigeria (Obadan \& Odusola, 2000). A high percentage of youth in Nigeria are unemployed, and graduate unemployment has been abysmally high (Adawo \& Atan, 2013). These high unemployment rates have resulted in an increase in social vices including prostitution, human trafficking, child labor, kidnapping, robbery and the recent recruitment of teenagers by the dreaded Boko Haram insurgents to bomb various locations throughout West Africa. Rising unemployment adversely affects economic growth because of declining aggregate demand/consumption and declining domestic investment, which subsequently re-enforce unemployment problems, because low production implies a reduction in the employment of factor inputs including labor.

It is not surprising that many Nigerians remain poor, and development in all spheres (economic, social and political, just to mention a few) remains stagnant in Nigeria. Therefore, this study is very important because it will provide policy direction regarding how to reduce unemployment, promote growth or achieve both over the long term. If Okun's law is valid for Nigeria, then the value of the coefficient can provide a guide regarding the amount of unemployment that must be reduced to achieve a certain level of output and vice versa.

Interestingly, unimpressive growth rates and high unemployment rates in Nigeria have attracted scholars to investigate the relationship between these two economic indicators (see Abraham, 2014; Akeju \& Olanipekun, 2015; Bankole \& Fatai, 2013; Jibir, Bappayaya, \& Babayo, 2015). These studies are beneficial, however, they have certain shortcomings. For example, Bankole and Fatai (2013) and Abraham (2014) used 29 years of annual data in their analysis. This falls short of the requirement for a time series analy- 

identical to the relationship of actual data for several countries. A negative correlation exists between revisions to unemployment forecasts and revisions to real GDP forecasts. Zagler (2003) employed a vector error correction model to analyze the relationship between the unemployment rate and economic growth for four major European countries, including France, Germany, Italy, and the United Kingdom. The results indicate that economic growth and the unemployment rate are cointegrated and positively correlated. This result refutes Okun's law. However, in the short run, an increasing equilibrium unemployment rate results in a decline in economic growth. This outcome is consistent with Okun's law.

Okun's law has been investigated at country-specific levels, particularly for developed countries. For example, Evans (1989) determined that a feedback relationship exists between the stochastic components of economic growth and the unemployment rate for the United States during 1950-1985. Farsio and Quade (2003) empirically investigated the connection between unemployment and GDP using twenty years of quarterly data for the United States. Using simple regression, the authors determined that the unemployment rate has a significant and negative effect on economic growth, however, the coefficient estimate is much less than Okun's estimate. Furthermore, the unemployment rate Granger causes economic growth, and this relationship was stable for various sub-periods. The authors concluded that Okun's coefficient varies for countries and across different samples. Hamada and Kurosaka (1984) evaluated the existence of Okun's law by examining the relationship between excess capacity and unemployment in the postwar Japanese economy by conducting a regression analysis. The authors discovered that the output gap's response to the unemployment rate is very high, rising to 28 percent. They attributed the large coefficient to the elastic response of factors, including changes in industrial structures, flexible working hours, slow adjustment in employment, and the female participation ratio. Nguyen and Siriwardan (1988) examined whether an Okun-type relationship occurs in Australia and if the relationship has been stable. Their findings appear to be plausible and lends support to the outcomes of prior studies.
Scholars have examined Okun's law by using unemployment and output cycles. For example, Weber (1995) estimated Okun's coefficient for postwar United States using new estimates of cyclical unemployment rates and cyclical output (GNP). The evidence indicates that the coefficient is almost -0.26 , which is less than the results calculated by prior studies that used similar econometric approaches to analyze different estimates of the cyclical unemployment rate and cyclical output. Apergis and Rezitis (2003) used HodrickPrescott filtering and bandpass filtering techniques to estimate Okun's coefficient for certain regions in Greece from 1960 to 1997 . The results illustrate that there are no substantial differences in the coefficients across the regions, with the exception of two of the regions (Epirus and North Aegean Islands). In addition, the results reveal that the estimates for these two regions are greater than the regional average. Silvapulle et al. (2004) tested Okun's hypothesis using a dynamic model that allows for asymmetry in the relationship between cyclical output and cyclical unemployment using 1947:1-1999:4 data for the United States. The results demonstrate that the short-term impacts of positive cyclical output on cyclical unemployment are quantitatively different than the impacts of negative cyclical output. In addition, cyclical unemployment is more responsive to negative cyclical output than positive cyclical output.

Adanu (2005) employed the Hodrick-Prescott detrending method and the quadratic detrending method to estimate Okun's coefficient for 10 Canadian provinces. The results included average coefficients of -1.58 and -1.32 for the Hodrick-Prescott detrending method and quadratic detrending method, respectively. Huang and Lin (2006) used the flexible nonlinear inference approach proposed by Hamilton (2001) to examine the validity of Okun's law in the United States from 1948:1 to 2004:2. The results illustrate that there is a negative and nonlinear relationship between cyclical components of unemployment and output.

Numerous studies have analyzed the relationship between unemployment and output growth by focusing on states/regions within countries or simultaneously focusing on a country and the states/regions within that country. For example, Blackley (1991) estimated Okun's coefficient for 26 states in the United States. The author determined that an average of 3.1 

Notably the few studies regarding the unemployment-output nexus in Nigeria used inadequate sample data (see Abraham, 2014; Bankole \& Fatai, 2013), employed inappropriate estimation methods or failed to conduct important tests (see Jibir et al., 2015). Jibir et al. (2015) should not have used the OLS method because some of the data used for analysis had a unit root. Furthermore, the authors did not conduct post estimation tests such as serial correlation and heteroscedasticity tests to ensure that the estimates were free from these problems. In addition, Osinubi (2005) did not perform a unit root test on the data used in his study. Therefore, this study fills a gap by estimating the Okun-type relationship in Nigeria using a recently developed ARDL bounds testing technique and conducting all the important tests (unit root test, diagnostic tests, etc.,) in addition to expanding the scope of the study (by analyzing, the data for 1970-2014).

\section{Theoretical framework}

This section establishes a connection between unemployment and output. Researchers have relied on Okun's law when examining the link between the unemployment rate and output growth. Okun's law can be explained as follows. As aggregate demand changes, firms/producers change their output plans, which causes variations in the demand for labor and subsequently, changes unemployment rates.

According to Farsio and Quade (2003), variations in unemployment likely lead to variations in output in the opposite direction. The authors argued that, although numerous factors cause variations in output, unemployment is the most visible because it has a direct impact on production. To a greater extent, many scholars believe that a reduction in the unemployment rate should increase the production of goods and services.

Two approaches were employed to estimate Okun's coefficient. The first is the output-gap approach, and the second involves using output growth and the first difference measure of the unemployment rate. Okun used the output-gap approach, where unemployment (UNEM) is dependent on deviations of actual output (GDP) from potential output (GDP). The relationship is specified as follows.

$U N E M-U N E M^{*}=a+b($ Output Gap $)$
Assuming that the output gap is computed as the firstdifference of output (economic growth rate), then a new equation is obtained as follows:

$\Delta U N E M_{t}=a-b\left(\frac{\Delta G D P}{G D P}\right)_{t}$

Conversely, Okun's law can be analyzed from the demand-side. Therefore, using the first-difference approach, output's response to variations in unemployment can be explained. The relationship can be expressed as follows:

$\left(\frac{\Delta G D P}{G D P}\right)_{t}=a-b \Delta U N E M_{t}+\varepsilon_{t}$

Or

$\Delta \log G D P_{t}=a-b^{*} \Delta U N E M+\varepsilon_{t}$

Equation 4 clearly indicates that output is dependent on unemployment (UNEM), and that the relationship between the variables is negative. The estimate of the coefficient ' $b$ ' represents Okun's coefficient.

For the purpose of this study, we follow Farsio and Quade (2003) and hypothesize that a decrease in the unemployment rate will cause output to expand. This implies that the growth rate for GDP (GDP) and the unemployment rate (UNEM) should be negatively related. The relationship can be specified as follows.

$\Delta G D P_{t}=\alpha_{0}-\alpha_{1} \Delta U N E M_{t}+\varepsilon_{t}$

Nigeria is one of the largest producers and exporters of oil. Oil accounts for a considerable portion of $\mathrm{Ni}$ geria's GDP and government revenues. Recently, oil prices soared and jumped from US\$50.59 in 2005 to US\$109.45 in 2012, before declining to US\$96.29 in 2014. This increase in the price of oil may have (to a greater extent) contributed to the high growth rates in Nigeria during that time. Considering the possible impacts of oil prices, the model is re-specified to include oil prices (OIL) as follows:

$\Delta G D P_{t}=\alpha_{0}-\alpha_{1} \Delta U N E M_{t}+\alpha_{2} \Delta O I L_{t}+\varepsilon_{t}$

\section{Method and data}

This study uses annual data for 1970-2014 to examine the presence of Okun's law in Nigeria. Data for eco- 
Table 1. Results of Unit Root Tests (with intercept only)

\begin{tabular}{lcccccc}
\hline & \multicolumn{2}{c}{ ADF } & \multicolumn{2}{c}{ PP } & \multicolumn{2}{c}{ Ng-P } \\
\hline Variable & Level & $1^{\text {st }}$ Diff & Level & $1^{\text {st }}$ Diff & Level & $1^{\text {st }}$ Diff \\
GDP & $-5.7973^{* * *}$ & - & $-5.8069^{* * *}$ & - & -1.0542 & $-3.1966^{* * *}$ \\
UNEM & -2.1386 & $-4.7336^{* * *}$ & -2.1386 & $-4.4473^{* * *}$ & -1.8939 & $-2.1209^{* *}$ \\
OIL & -0.2980 & $-6.9898^{* * *}$ & -0.2127 & $-7.0435^{* * *}$ & 0.2203 & $-3.2278^{* * *}$ \\
\hline
\end{tabular}

Note: ${ }^{* * *}$ denotes statistical significance at the $1 \%$ level.

nomic growth (measured by growth in the real gross domestic product) were collected from the World Bank World Development Indicators and data for unemployment rate were obtained from various sources including the Nigeria Bureau of Statistics (NBS), the Central Bank of Nigeria (CBN, various years), and Adawo, Essien and Ekpo (2012). Data for average oil prices were collected from the Organization of Petroleum Exporting Countries (OPEC) and the International Energy Association (IEA).

\section{Unit root tests}

Although economic theory requires a series to be stationary prior to estimating the relationship between the series, the ARDL approach used in this study does not require testing unit root for variables. Neverthelsss, it is important to perform the unit root test because the existence of a second order integration (i.e., I(2)) of any series (variable) used in estimation invalidates the use of the ARDL technique. To clarify, if an I(2) variable is included in the ARDL model, it will produce meaningless results.

To conduct the unit root test, we employed three statistics including Augmented Dicker-Fuller (ADF), Philips-Perron (PP) and Ng-Perron (Ng-P). The ADF, $\mathrm{PP}$ and Ng-P tests test the null hypothesis that a series has a unit root against the alternative hypothesis that the series does not have a unit root. The results of the unit root tests are presented in Table 1, and demonstrate that all series (GDP, UNEM and OIL) are a mixture of $\mathrm{I}(0)$ and $\mathrm{I}(1)$. For example, the ADF and PP tests indicate that GDP is $\mathrm{I}(0)$, but the Ng-P test indicates that it is $\mathrm{I}(1)$. In addition, all three tests demonstrate that UNEM and OIL are I(1).

Having established that the series are a combination of $\mathrm{I}(0)$ and $\mathrm{I}(1)$, we employ the ARDL bounds testing technique (Pesaran \& Shin, 1999; Pesaran, Shin, \& Smith, 2001) to estimate the relationship between the variables. The ARDL model to be estimated is specified as follows:

$$
\begin{aligned}
& \Delta G D P_{t}=\alpha_{0}+\sum_{i=1}^{n} \alpha_{1 i} \Delta G D P_{t-i}+\sum_{i=0}^{n} \alpha_{2 i} \Delta U N E M_{t-i}+ \\
& +\sum_{i=0}^{n} \alpha_{3 i} \Delta O I L_{t-i}+\delta_{1} G D P_{t-1}+\delta_{2} U N E M_{t-1}+\delta_{3} O I L_{t-1}+\varepsilon_{1 t}
\end{aligned}
$$

The first portion of the above calculation includes changes $(\Delta s)$ in the unemployment rate, the GDP growth rate and oil prices, and the second portion includes the GDP growth rate, the unemployment rate and oil prices.

\section{ARDL bounds testing for cointegration}

The ARDL method is utilized because of its advantages over other cointegration methods such as the residual-based technique (Engle \& Granger, 1987) and the maximum likelihood test (Johansen, 1988, 1991; Johansen \& Juselius, 1990), which have been discussed extensively (see Nyasha \& Odhiambo, 2015; Ozturk \& Acaravci, 2010; 2011; Tang \& Shahbaz, 2011; Vlahinic \& Jakovac, 2014). For example, the ARDL method can be used to examine cointegration relationships regardless of the order of integration of the series, $\mathrm{I}(0)$, I(1) or a mixture of both. In addition, residual-based techniques, such as the Johansen cointegration technique, requires a large sample size for validity, however, the ARDL approach is better for validating that a cointegrating relationship exists in small samples. Furthermore, unlike other conventional cointegration techniques, the ARDL method allows the variables to have different optimal lags. Finally, other conventional cointegration techniques estimate the long term relationships using system equations, however, the ARDL 
Table 2. Results from Bounds Tests (1970-2014)

\begin{tabular}{|c|c|c|c|c|}
\hline Dependent Variable & & Function & & F-Statistic \\
\hline GDP & F(GDP/UNEM,OIL) & & & $11.129^{* * *}$ \\
\hline \multicolumn{5}{|l|}{ Asymptotic Critical Values } \\
\hline & \multicolumn{2}{|c|}{$1 \%$} & \multicolumn{2}{|c|}{$5 \%$} \\
\hline & $\mid(0)$ & $\mid(1)$ & $\mathrm{I}(0)$ & $\mid(1)$ \\
\hline Narayan (2005), Case III & 5.920 & 7.197 & 4.083 & 5.207 \\
\hline
\end{tabular}

Note: ${ }^{* * *}$ denotes statistical significance at the $1 \%$ level.

technique uses a single reduced form equation to simultaneously estimate the long run and short run parameters of the model.

The ARDL bounds test is used to test the null hypothesis that no cointegration exists again the alternative hypothesis that cointegration exists. The computed F-statistic is compared with the critical values provided by Pesaran et al. (2001) and/or Narayan (2005). The critical values computed by Pesaran et al. (2001) are not suitable for small sample, which necessitates the use of Narayan's (2005) critical values. When the computed F-statistic is greater than the upper bound (I(1)), we reject the null hypothesis that no cointegration exists between the series. If the F-statistic is less than the lower bound $(\mathrm{I}(0))$, we accept the null hypothesis that there is no cointegration between the series. Furthermore, if the F-statistic falls between $\mathrm{I}(0)$ and $\mathrm{I}(1)$, our inference would be inconclusive.

\section{Results and discussion}

The results from bounds testing to cointegration are reported in Table 2. The results demonstrate that the computed F-statistic (11.129) is greater than I(1) at the $1 \%$ level. This result implies that a cointegrating relationship exists between the unemployment rate and economic growth (and oil prices).

\section{Results of selected long run and short run models}

Once the long run relationship between the variables had been confirmed, the ARDL model was estimated. The optimal lag-length suggested by the Akaike information criterion (AIC) is $(1,1,1)$. The long run and short run results for the selected models are presented in Table 3. The long run results (Panel A) illustrate that the unemployment rate has a long term negative and sig- nificant effect on economic growth at the $10 \%$ level. A $1 \%$ increase in the unemployment rate leads to a $0.18 \%$ decrease in economic growth in the long term. Furthermore, the results demonstrate that oil prices have a significant and positive effect on economic growth in the long term at the $5 \%$ level. A 1 dollar increase in the price of oil leads to a $0.99 \%$ increase in economic growth in the long term. The short run results (Panel B) indicate that unemployment and oil prices do not have a significant effect on economic growth in the short term.

The coefficient of the error correction term lagged by one period $\left(\mathrm{ECT}_{\mathrm{t}-\mathrm{I}}\right)$ is negative and statistically significant, and, therefore meets our expectation. The sign of the coefficient indicates a high speed of adjustment to equilibrium after a shock and indicates that approximately $92 \%$ of the deviations or disequilibrium in economic growth will be corrected within one year.

\section{Results of diagnostic tests}

The results reported in Table 4 reveal that the ARDL model passes the diagnostic tests including serial correlation (with 2-lags), functional form and heteroscedasticity. In addition, the plots of the cumulative sum of recursive residuals (CUSUM) and the cumulative sum of squares of recursive residuals (CUSUMQ) (Figure 2 and Figure 3 ) are within the boundaries. These tests confirm the stability of the model.

In addition, we examined the relationship between economic growth and the unemployment rate during 1972-2004, because of the high instability exhibited by both economic growth and the unemployment rate during this period. Osinubi (2005) conducted a study for a similar period (1970-2000) that revealed a positive relationship between economic growth and the unemployment rate. The results of the bounds testing 
Table 3. Results of the ARDL Model (1970-2014)

\begin{tabular}{|c|c|c|c|c|}
\hline \multicolumn{5}{|c|}{ Panel A: Long Run Coefficients - Dependent variable is GDP } \\
\hline Regressor & Coefficient & Standard Error & T-Ratio & Prob \\
\hline C & 0.9441 & 1.9505 & 0.4791 & 0.6346 \\
\hline UNEM & -0.1789 & 0.0918 & -1.9475 & 0.0589 \\
\hline OIL & 0.9920 & 0.4126 & 2.4037 & 0.0212 \\
\hline \multicolumn{5}{|c|}{ Panel B: Short Run Coefficients - Dependent variable is $\Delta$ GDP } \\
\hline Regressor & Coefficient & Standard Error & T-Ratio & Prob \\
\hline$\triangle U N E M$ & 0.0423 & 0.1044 & 0.4056 & 0.6873 \\
\hline$\triangle \mathrm{OIL}$ & 0.1459 & 0.2506 & 0.5824 & 0.5637 \\
\hline ECTt-1 & -0.9161 & 0.1321 & -6.9304 & 0.0000 \\
\hline R2 & 0.5401 & & & \\
\hline F-stat & 8.9262 & & & 0.0000 \\
\hline D.W-stat & 2.1329 & & & \\
\hline
\end{tabular}

Note: $\Delta$ is the first difference operator.

Source: Author's computation using Eviews version 9.

Table 4. ARDL-ECM Model Diagnostic Tests (1970-2014)

\begin{tabular}{lc}
\hline Test Statistic & Results \\
\hline Serial Correlation: CHSQ(2), 2-lags & $2.0083[0.3644]$ \\
Functional Form: Reset F-stat(1,37) & $0.6225[0.4351]$ \\
Normality: Jarque-Bera & $11.7328[0.0028]$ \\
Heteroscedasticity: CHSQ(11) & $3.7547[0.5852]$ \\
\hline
\end{tabular}

Note: Source: Author's computation using Eviews version 9

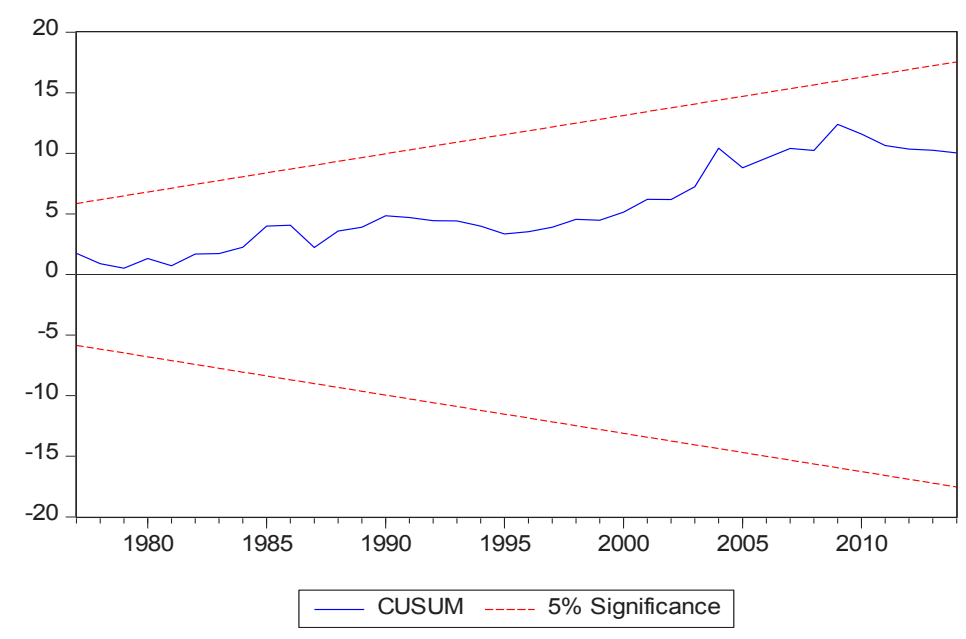

Figure 2. Plots of the cumulative sum of recursive residuals 


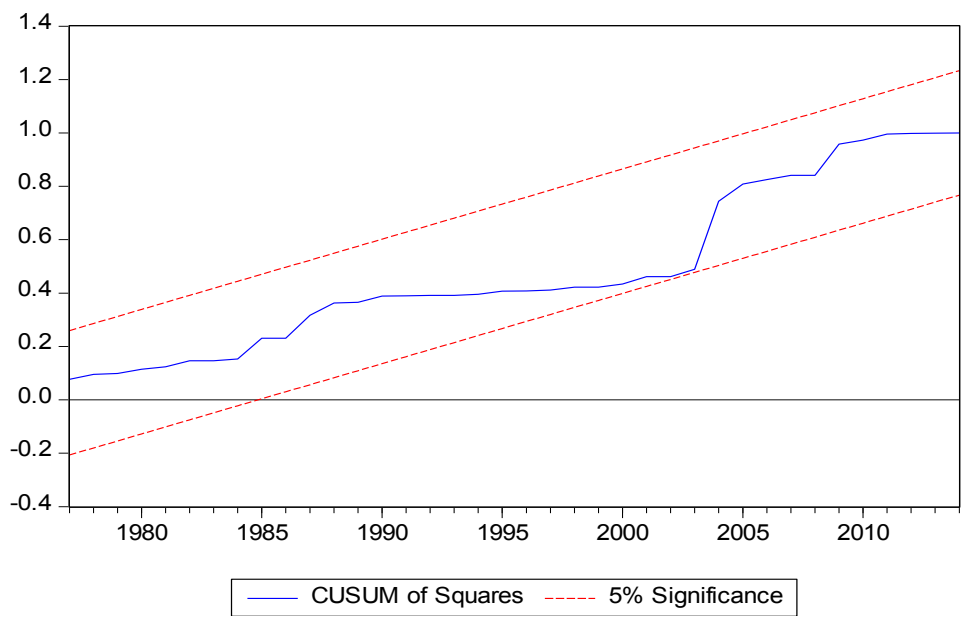

Figure 3. Plots of the cumulative sum of squares of recursive residuals

Table 5. Results from Bounds Tests (1972-2004)

\begin{tabular}{|c|c|c|c|c|}
\hline Dependent Variable & & Function & & F-Statistic \\
\hline GDP & & F(GDP/UNEM,OIL) & & $5.338^{* *}$ \\
\hline \multicolumn{5}{|l|}{ Asymptotic Critical Values } \\
\hline & \multicolumn{2}{|c|}{$5 \%$} & \multicolumn{2}{|c|}{$10 \%$} \\
\hline & $\mathrm{I}(0)$ & $\mathrm{l}(1)$ & $\mathrm{I}(0)$ & $\mathrm{I}(1)$ \\
\hline Narayan (2005), Case III & 4.183 & 5.333 & 3.393 & 4.410 \\
\hline
\end{tabular}

Note: ${ }^{* *}$ denotes statistical significance at the $5 \%$ level.

Table 6. Results of the ARDL Model (1972-2004)

\section{Panel A: Long Run Coefficients - Dependent variable is GDP}

\begin{tabular}{lcccc}
\hline Regressor & Coefficient & Standard Error & T-Ratio & Prob \\
\hline C & 1.5810 & 1.3228 & 1.1952 & 0.2432 \\
UNEM & 0.9561 & 0.5497 & 1.7391 & 0.0943 \\
OIL & -0.2427 & 0.2576 & -0.9419 & 0.3553 \\
\hline
\end{tabular}

Panel B: Short Run Coefficients - Dependent variable is $\Delta$ GDP

\begin{tabular}{|c|c|c|c|c|}
\hline Regressor & Coefficient & Standard Error & T-Ratio & Prob \\
\hline$\triangle U N E M$ & -0.9429 & 0.6282 & -1.5009 & 0.1459 \\
\hline$\triangle \mathrm{OIL}$ & 0.6304 & 0.2587 & 2.4361 & 0.0223 \\
\hline $\mathrm{ECT}_{\mathrm{t}-1}$ & -0.8536 & 0.2053 & -4.1563 & 0.0000 \\
\hline $\mathrm{R}^{2}$ & 0.5433 & & & \\
\hline F-stat & 5.9502 & & & 0.0009 \\
\hline D.W-stat & 1.6511 & & & \\
\hline
\end{tabular}

Note: $\Delta$ is the first difference operator

Source: Author's computation using Eviews version 9. 
Table 7. ARDL-ECM Model Diagnostic Tests (1972-2004)

\begin{tabular}{ll}
\hline Test Statistic & Results \\
\hline Serial Correlation: CHSQ(2), 2-lags & $0.2972[0.8619]$ \\
Functional Form: Reset F-stat(1,24) & $2.0829[0.1619]$ \\
Normality: Jarque-Bera & $1.4506[0.4841]$ \\
Heteroscedasticity: CHSQ(5) & $7.9525[0.1589]$ \\
\hline
\end{tabular}

Note: Source: Author's computation using Eviews version 9

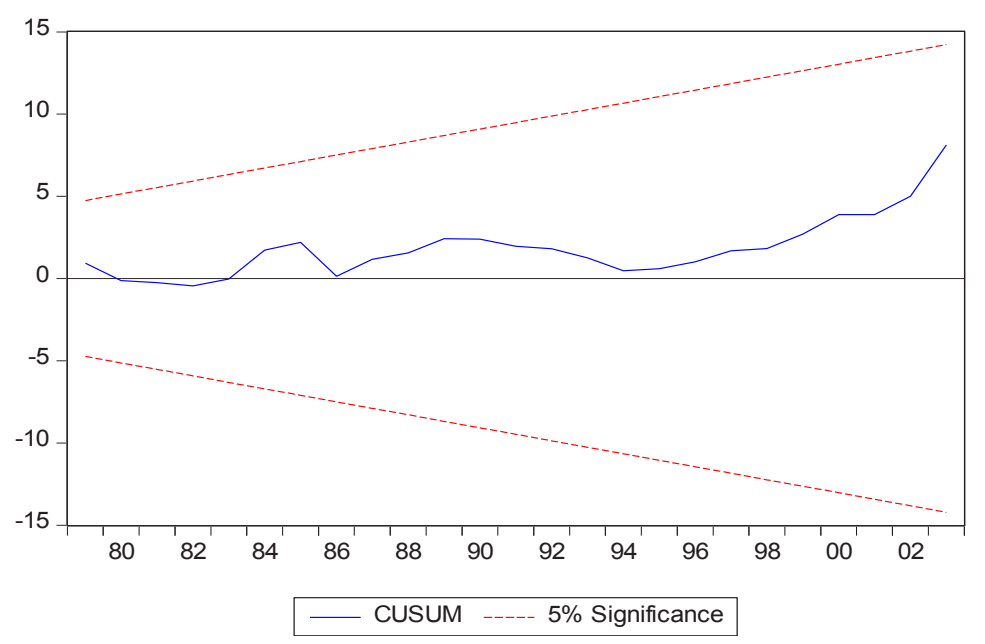

Figure 4. Plots of the cumulative sum of recursive residuals

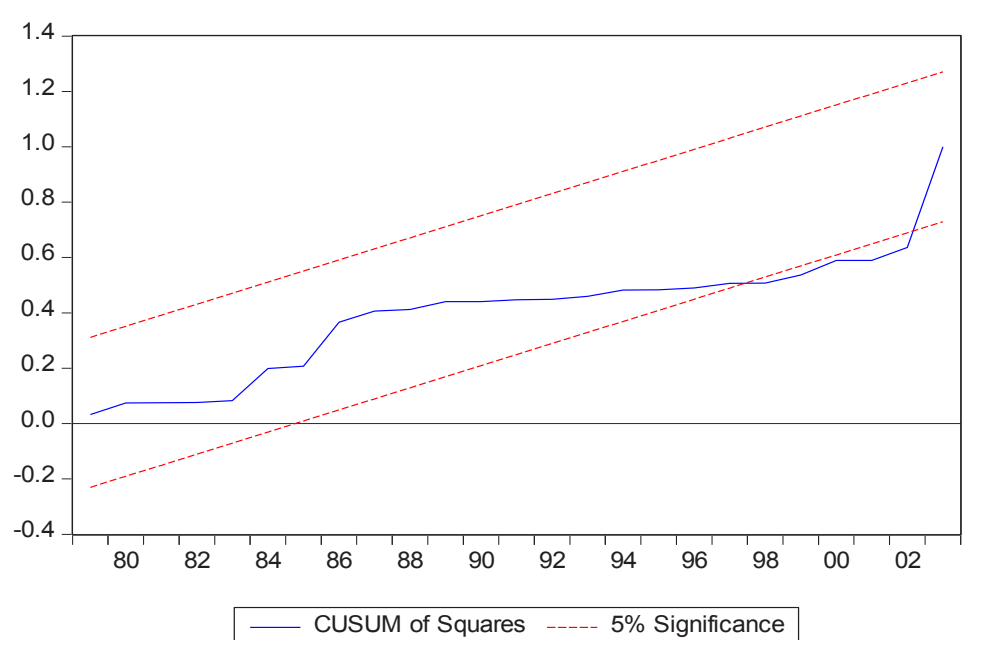

Figure 5. Plots of the cumulative sum of squares of recursive residuals 
to cointegration (Table 5) suggest that the variables are cointegrated, because the computed F-statistic (5.338) is larger than $\mathrm{I}(1)$ at the $5 \%$ level.

The long run and short run results of the estimated ARDL model for 1972-2004 period are reported in Table 6. The optimal lag-length indicated by the AIC is $(1,1,1)$. The long run results (Panel A) demonstrate that the unemployment rate has a significant and positive effect on the economic growth at the $10 \%$ level, but that oil prices do not have a significant effect on economic growth. The short run results (Panel B) reveal that unemployment does not have a significant effect on economic growth, but oil prices have a significant and positive effect on economic growth at the $5 \%$ level. A 1 dollar increase in the price of oil leads to a $0.63 \%$ increase in economic growth in the long term. The positive sign of the coefficient of unemployment lends support to Osinubi (2005) who confirmed a positive coefficient for Nigeria during 1970-2000.

The coefficient of the error correction term lagged by one period $\left(\mathrm{ECT}_{\mathrm{t}-1}\right)$ is negative and statistically significant, and therefore, meets our expectation. The sign of the coefficient indicates a high speed of adjustment to equilibrium after a shock and indicates that approximately $85 \%$ of the deviations or disequilibrium in economic growth will be corrected within one year.

\section{Results of diagnostic tests}

The results reported in Table 7 reveal that the ARDL model passes the diagnostic tests including serial correlation (with 2-lags), functional form and heteroscedasticity. In addition, the plots of the cumulative sum of recursive residuals (CUSUM) and the cumulative sum of squares of recursive residuals (CUSUMQ) (Figure 4 and Figure 5) are within the boundaries. These confirms the stability of the model.

Overall, the results of the estimation demonstrate that the coefficient of the unemployment rate is negative and significant during 1970-2014. However, the value of the coefficient $(0.18 \%)$ is far less than the value of 3\% in Okun's original work and other studies that focused on developed countries. This result lends support to the claim that the slope coefficient of Okun's model is not only unstable but also varies for different countries. Conversely, the coefficient is positive and significant during 1972-2004. This result is consistent with that of Osinubi (2005), who analyzed a similar period (1970-2000). The positive relationship between unemployment and growth reflects the situation in Nigeria, where individuals who are considered unemployed in the official sense still engage in certain types of employment that are not officially regarded as employment (Osinubi, 2005), and thereby contribute to production activity.

\section{Conclusion}

This study utilizes the ARDL bounds testing technique to examine Okun's law in Nigeria from 1970 to 2014, and considers the role of oil prices in the Nigerian economy. The results indicate a cointegrating relationship exists between the unemployment rate, economic growth, and oil prices. The results reveal that the unemployment rate has a long term negative and significant effect on economic growth, and that oil prices have a significant and positive effect on economic growth in the long term. The relatively low value of the coefficient suggests that Okun's coefficient is not only unstable, but also varies for different countries, and does not hold strictly for the Nigerian economy. The coefficient indicates that a 1 percentage increase in unemployment reduces economic growth by $0.18 \%$ in the long term, and vice versa. The long term negative effect of unemployment on growth has significant economic implications. An increase in the unemployment rate implies that more individuals are jobless and incomes are falling, which leads to decreased demand for goods and services and subsequently declining production. All of these economic issues re-enforce unemployment problems over the long term. Therefore, policymakers should take steps to reduce unemployment to promote economic growth in Nigeria.

\section{References}

Abraham, O. (2014). The effects of output shock on unemployment: An application of bounds testing approach to Nigeria. Journal of Economics and Sustainable Development, 5(23), 161-169.

Adanu, K. (2005). A cross-province comparison of Okun's coefficient for Canada. Applied Economics, 37(5), 561-570.

Adawo, M .A., Essien, E. B., \& Ekpo, N. U. (2012). Is Nigeria's unemployment problem unsolvable?. Current Research Journal of Social Sciences, 4(6), 389-395. 
Adawo, M. A., \& Atan, J. A. (2013). Graduate unemployment in Nigeria: Entrepreneurship and venture capital nexus. Journal of Economics and Sustainable Development, 4(9), 75-81.

Akeju, K. F., \& Olanipekun, D. B. (2015). Unemployment and economic growth in Nigeria. International Journal of African and Asian Studies, 11, 92-98.

Apergis, N., \& Rezitis, A. (2003). An examination of Okun's law: Evidence from regional areas in Greece. Applied Economics, 35(10), 1147-1151.

Ball, L., Leigh, D., \& Loungani, P. (2013). Okun's law: Fit at fifty? (Working Paper No. 18668). The National Bureau of Economic Research. Retrieved from http://www.nber.org/papers/w18668

Ball, L., Jalles, J. T., \& Loungani, P. (2015). Do forecasters believe in Okun's law? An assessment of unemployment and output forecasts. International Journal of Forecasting, 31(1), 176-184.

Bankole, A. S., \& Fatai, B. O. (2013). Empirical test of Okun's law in Nigeria. International Journal of Economic Practices and Theories, 3(3), 227-231.

Beaton, K. (2010). Time variation in Okun's law: A Canada and U.S. comparison (Working Paper No. 7). Bank of Canada. Retrieved from http://www. bankofcanada.ca/wp-content/uploads/2010/05/ wp10-7.pdf

Blackley, P. R. (1991). The measurement and determination of Okun's law: Evidence from state economies. Journal of Macroeconomics, 13(4), 641-656.

Engle, R. F., \& Granger, C. W. J. (1987). Co-integration and error correction: Representation, estimation, and testing. Econometrica, 55(2), 251-276.

Evans, G. W. (1989). Output and unemployment dynamics in the United States: 1950-1985. Journal of Applied Econometrics, 4(3), 213-237.

Farsio, F., \& Quade, S. (2003). An empirical analysis of the relationship between GDP and unemployment. Humanomics, 19(3), 1-6.

Hamada, K., \& Kurosaka,Y. (1984). The relationship between production and unemployment in Japan: Okun's law in comparative perspective. European Economic Review, 25(1), 71-94.

Hamilton, I. D. (2001). A parametric approach to flexible nonlinear inference, Econometrica, 69, 537-73.

Huang, H. C., \& Lin, S. C. (2006). A flexible nonlinear inference to Okun's relationship. Applied Economics Letters, 13(5), 325-331.
Huang, H. C., \& Yeh, C. C. (2013). Okun's law in panels of countries and states. Applied Economics, 45(2), 191-199.

Izyumov, A., \& Vahaly, J. (2002). The unemploymentoutput tradeoff in transition economies: Does Okun's law apply? Economics of Planning, 35(4), 317-331.

Jibir, A., Bappayaya, B., \& Babayo, H. (2015). Reexamination of the impact of unemployment on economic growth of Nigeria: An econometric approach. Journal of Economics and Sustainable Development, 6(8), 116-123.

Johansen, S. (1988). Statistical analysis of cointegration vectors. Journal of Economic Dynamics and Control, 12(2-3), 231-254.

Johansen, S. (1991). Estimation and hypothesis testing of cointegration vectors in Gaussian vector autoregressive models. Econometrica, 59(6), 1551-1580.

Johansen, S., \& Juselius, K. (1990). Maximum likelihood estimation and inference on cointegration - With applications to the demand for money. Oxford Bulletin of Economics and Statistics, 52(2), 169-210.

Kamgnia, D. B. (2009). Growth intensity of employment in Africa - A panel data approach. Applied Econometrics and International Development, 9(2), 161-174.

Kargi, B. (2014). Okun's law and long term co-integration analysis for OECD countries (1987-2012). International Research Journal of Finance and Economics, 119, 77-85.

Kuscevic, C. M. M. (2014). Okun's law and urban spillovers in US unemployment. The Annals of Regional Science, 53(3), 719-730.

Moosa, I. A. (1997). A cross-country comparison of Okun's coefficient. Journal of Comparative Economics, 24(3), 335-356.

Narayan, P. K. (2005). The saving and investment nexus for China: Evidence from cointegration tests. Applied Economics, 37(17), 1979-1990.

Nguyen, D. T., \& Siriwardan, A. M. (1988). The relationship between output growth and unemployment: A re-examination of Okun's law in Australia. The Australian Economic Review, 21(1), 16-27.

Noor, Z. M., Nor, N. M., \& Ghani, J. A. (2007). The relationship between output and unemployment in Malaysia: Does Okun's law exist? International Journal of Economics and Management, 1(3), 337-344. 
Nyasha, S., \& Odhiambo, N. M. (2015). The impact of banks and stock market development on economic growth in South Africa: An ARDL-bounds testing approach. Contemporary Economics, 9(1), 93-108.

Obadan, M. I., \& Odusola, A. F. (2000). Productivity and unemployment in Nigeria. Ibadan, Nigeria: National Centre for Economic Management \& Administration.

Osinubi, T. S. (2005). Macroeconometric analysis of growth, unemployment and poverty in Nigeria. Pakistan Economic and Social Review, 43(2), 249-269.

Ozturk, I., \& Acaravci, A. (2010). The causal relationship between energy consumption and GDP in Albania, Bulgaria, Hungary and Romania: Evidence from ARDL bounds testing approach. Applied Energy, 87(6), 1938-1943.

Ozturk, I., \& Acaravci, A. (2011). Electricity consumption and real GDP causality nexus: Evidence from ARDL bounds testing approach for 11 MENA countries. Applied Energy, 88(8), 2885-2892.

Pereira, R. M. (2014). Okun's law, asymmetries and regional spillovers: evidence from Virginia metropolitan statistical areas and the District of Columbia. The Annals of Regional Science, 52(2), 583-595.

Pesaran, M. H., \& Shin, Y. (1999). An autoregressive distributed lag modeling approach to cointegration analysis. In S. Strøm (Ed.), Econometrics and economic theory in the 20th century: The Ragnar Frisch Centennial Symposium. Eeconometric society monographs (Vol. 31, pp. 1-31). Cambridge, UK: Cambridge University Press.

Pesaran, M. H., Shin, Y., \& Smith, R. J. (2001). Bounds testing approaches to the analysis of level relationships. Journal of Applied Econometrics, 16(3), 289326.

Pierdzioch, C., Rülke, J. C., \& Stadtmann, G. (2011). Do professional economists' forecasts reflect Okun's law? Some evidence for the G7 countries. Applied Economics, 43(11), 1365-1373.

Silvapulle, P., Moosa, I. A., \& Silvapulle, M. J. (2004). Asymmetry in Okun's law. Canadian Journal of Economics, 37(2), 353-374.

Sögner, L. (2001). Okun's law: Does the Austrian unemployment-GDP relationship exhibit structural breaks? Empirical Economics, 26(3), 553-564.
Tang, C. F., \& Shahbaz, M. (2011). Revisiting the electricity consumption-growth nexus for Portugal: Evidence from a multivariate framework (MPRA Working Paper No. 28393). University Library of Munich, Germany.

Villaverde, J., \& Maza, A. (2009). The robustness of Okun's law in Spain, 1980-2004 regional evidence. Journal of Policy Modeling, 31, 289-297. Retrieved from https://mpra.ub.uni-muenchen.de/28393/1/ MPRA_paper_28393.pdf

Vlahinic, N., \& Jakovac, P. (2014). Revisiting the energy consumption-growth nexus for Croatia: New evidence from a multivariate framework analysis. Contemporary Economics, 8(4), 435-452.

Weber, C. E. (1995). Cyclical output, cyclical unemployment, and Okun's coefficient: A new approach. Journal of Applied Econometrics, 10(4), 433-445.

Zagler, M. (2003). The Dynamics of Economic Growth and Unemployment in Major European Countries: Analysis of Okun's Law. Applied Econometrics and International Development, 3(3), 93-118. 